Ambiente \& Água - An Interdisciplinary Journal of Applied Science
ISSN 1980-993X - doi:10.4136/1980-993X
www.ambi-agua.net
E-mail: ambi.agua@gmail.com

\title{
Assessment of trace metals in Amazonian fish exposed to untreated urban sewage: high chromium concentrations in fish tissues
}

\author{
doi: 10.4136/ambi-agua.1594
}

Received: 16 Jan. 2015; Accepted: 30 Mar. 2015

\author{
Eduardo Araujo de Sousa ${ }^{1 *}$; Márcio Rodrigues Miranda ${ }^{1}$; \\ Marília Hauser dos Santos²; Walkimar Aleixo Costa Júnior; \\ Leidiane Caroline Lauthartte ${ }^{1}$; Marília Higino Mussy ${ }^{1}$; \\ Igor Bruno Barbosa de Holanda ${ }^{1}$; Wanderley Rodrigues Bastos ${ }^{1}$ \\ ${ }^{1}$ Universidade Federal de Rondônia (UNIR), Porto Velho, RO, Brasil. \\ Laboratório de Biogeoquímica Ambiental Wolfgang Christian Pfeiffer \\ ${ }^{2}$ Universidade Federal de Rondônia (UNIR), Porto Velho, RO, Brasil \\ Laboratório de Ictiologia e Pesca \\ *Corresponding author: e-mail: edu-d20@hotmail.com, \\ marcio.ltwcp@hotmail.com, mariliahauser@yahoo.com.br, \\ walkimarcosta@gmail.com, leidianequimica@gmail.com, \\ mariliamussy@hotmail.com, igorbruno16@gmail.com, \\ wanderbastos@yahoo.com.br
}

\begin{abstract}
The aim of this study was to evaluate the quality of fish meat in relation to inorganic contaminants $(\mathrm{Zn}, \mathrm{Pb}, \mathrm{Cu}, \mathrm{Cr}, \mathrm{Ni}$ and $\mathrm{Hg}$ ), following the Brazilian Health Surveillance Agency (ANVISA) standards in five Amazonian fish exposed to untreated urban sewage. Trace metal concentrations were evaluated in the muscle tissues of Schizodon fasciatus (herbivorous), Potamorhina latior (detritivorous), Triportheus angulatus (omnivorous), Plagioscion squamosissimus (carnivorous) and Rhaphiodon vulpinus (piscivorous), sampled upstream and downstream of Santo Antônio's Hydroelectric Dam, Madeira River (Porto Velho City, Brazil). An acid chemical digestion was used to extract trace metals from the tissues, and atomic absorption spectrometry methods were used to quantify the trace metal concentrations. Fish samples showed values above allowed limits for $\mathrm{Cr}\left(0.10 \mathrm{mg} \cdot \mathrm{kg}^{-1}\right)$, except in Plagioscion squamosissimus $\left(0.09 \mathrm{mg} \cdot \mathrm{kg}^{-1}\right)$. Potamorhina latior specimens sampled downstream showed higher values for $\mathrm{Cr}(\mathrm{p}<0.0001)$ than specimens sampled upstream. This result may indicate that untreated urban sewage discharged into the river downstream is influencing the $\mathrm{Cr}$ concentrations. As only $\mathrm{Cr}$ exceeded the allowed value for consumption, the estimated daily intake of $\mathrm{Cr}$ in the Brazilian urban and riverine population was calculated based on their fish consumption for each species sampled upstream and downstream. Estimates of daily intake of $\mathrm{Cr}$ were higher in fish sampled downstream than upstream, and were 13 times higher in the riverine population than in the Brazilian urban population.
\end{abstract}

Keywords: ANVISA, bioaccumulation, daily intake, fish consumption, Madeira River. 


\section{Avaliação de metais traços em peixes amazônicos expostos à esgoto urbano não tratado: altas concentrações de cromo em tecidos de peixes}

\section{RESUMO}

O objetivo desse estudo foi avaliar a qualidade do peixe em relação a contaminantes inorgânicos ( $\mathrm{Zn}, \mathrm{Pb}, \mathrm{Cu}, \mathrm{Cr}, \mathrm{Ni}$ e $\mathrm{Hg}$ ), seguindo as determinações da Agência Nacional de Vigilância Sanitária (ANVISA) em cinco espécies de peixes amazônicos expostos à esgoto urbano não tratado. As concentrações de metais traços foram avaliadas em tecidos musculares de Schizodon fasciatus (herbívoro), Potamorhina latior (detritívoro), Triportheus angulatus (onívoro), Plagioscion squamosissimus (carnívoro) e Rhaphiodon vulpinus (piscívoro) coletados a montante e a jusante da Usina Hidrelétrica de Santo Antônio, rio Madeira (Porto Velho, Brasil). Para a extração dos metais traços dos tecidos musculares, foi utilizada uma digestão química ácida. Para quantificar as concentrações dos metais traços, foram utilizadas técnicas de espectrometria de absorção atômica. As amostras de peixes apresentaram valores acima do permitido somente para $\mathrm{Cr}\left(0,10 \mathrm{mg} . \mathrm{kg}^{-1}\right)$, exceto em $P$. squamosissimus $\left(0,09 \mathrm{mg} \cdot \mathrm{kg}^{-1}\right)$. Espécimes de $P$. latior coletados a jusante, apresentaram maiores concentrações de $\mathrm{Cr}(\mathrm{p}<0,0001)$ que espécimes coletados a montante. Tal fato, talvez indique que os despejos de esgoto urbano não-tratado dentro do rio (jusante), estejam influenciando nas concentrações de $\mathrm{Cr}$. Pelo fato do $\mathrm{Cr}$ ter ultrapassado o valor permitido para consumo, foi calculado a ingestão diária estimada de $\mathrm{Cr}$ em população urbana brasileira e ribeirinha baseados em seus respectivos consumos de peixe, a partir de cada espécie coletada a montante e a jusante. A ingestão diária estimada de cromo apresentou maiores valores a partir do consumo de peixes da jusante e os valores foram 13 vezes maiores na população ribeirinha do que na população urbana brasileira.

Palavras-chave: ANVISA, bioacumulação, consumo de peixe, ingestão diária, Rio Madeira.

\section{INTRODUCTION}

Fish is one of the most important sources of animal protein for Amazonian population, especially for riverine communities (Bastos et al., 2008). The Madeira River Basin is the main source of fish for the population of the state of Rondônia (Brazil), especially the cities of Porto Velho and Guajará-Mirim (Doria et al., 2012). According to Oliveira et al. (2010), daily fish consumption in Amazonian riverine communities is high (406 g/day) and shows an integrated yearly consumption of $148.2 \mathrm{~kg} /$ person. In contrast, average Brazilian fish consumption is $11.17 \mathrm{~kg}$ per year (Brasil, 2013).

There are many ecological risk assessment studies focused on fish contamination by mercury in the Madeira River Basin, due the historical gold rush in the region between 1970s and 1990s. It is estimated that $100 \mathrm{t}$ of $\mathrm{Hg}$ were released into the atmosphere and the aquatic system (Pfeiffer and Lacerda, 1988; Maurice-Bourgoin et al., 2000; Bastos et al., 2006; 2007). However, data on contaminants such as lead $(\mathrm{Pb})$, nickel $(\mathrm{Ni})$, chromium $(\mathrm{Cr})$, zinc $(\mathrm{Zn})$ and copper $(\mathrm{Cu})$, among others, are scarce or non-existent. Heavy metals are an important class of pollutants and have major detrimental impacts on both human and environmental health (Boyd, 2010). Environmental contamination by anthropogenic sources raises important questions, such as how much of a potential pollutant might be released into the environment and under what conditions, and how does the contaminant transform in the environment and what are the effects on man and his environment (National Academy of Sciences, 1975).

Fish are most habitually used as target organisms in developing criteria and setting standards for water quality (Welch and Jacoby, 2004). High trace metals concentrations may affect local fish biodiversity and stock by decreasing growth rate and reproduction and 
causing changes in behavioral patterns (Mishra and Mohanty, 2009; Subotic et al., 2013; Nagpure et al., 2015).

Porto Velho City releases untreated urban sewage directly into the Madeira River. Santos et al. (2012) demonstrated that domestic effluents discharged into streams and the inappropriate disposal of solid waste contributed to an increased concentration of trace elements in several water bodies. This contaminant input may affect aquatic biota and bioaccumulation in fish (Santos et al., 2012). Other local contaminant sources of the Madeira River Basin are fertilizers and soil amendments (Santos et al., 2012).

This study aims: i) to assess the concentration of copper, nickel, lead, zinc, mercury and chromium in muscle tissue of fish from the Madeira River Basin; ii) to verify if the values are in agreement with those established by ANVISA regarding food and daily intake; iii) to determine whether Porto Velho City urban sewage has a significant influence on trace metal concentrations in fish; and iv) to estimate daily chromium intake according to the Brazilian Health Surveillance Agency (ANVISA) standards.

\section{MATERIALS AND METHODS}

\subsection{Study Area}

The study area (Figure 1) includes eight sampling sites, five sites located upstream and three downstream of the Santo Antônio's Hydroelectric Dam. Santo Antônio's Hydroelectric Dam may be considered an artificial barrier that prevents the movement of species between the upstream and downstream areas. Although there is a fish passage in the dam, studies have shown that fish passages in South America are ineffective in selective species (Pelicice and Agostinho, 2008; Pompeu et al., 2012). No studies have proven that the species analyzed in our study move freely between upstream and downstream.

Samples from five sampling sites were collected in the upstream area. These sites were: Jaci Paraná River sites JAM (upstream Jaci Paraná District) and RSJ (downstream Jaci Paraná District); upper (RSA) and lower (RSB) Santo Antônio's reservoir (Madeira River) and Jatuarana I Stream (RST). Within the downstream area, samples were collected at three stations: Jatuarana II Stream (JAD); Belmont Stream's mouth (BEF) and Cuniã Lake (CUN).

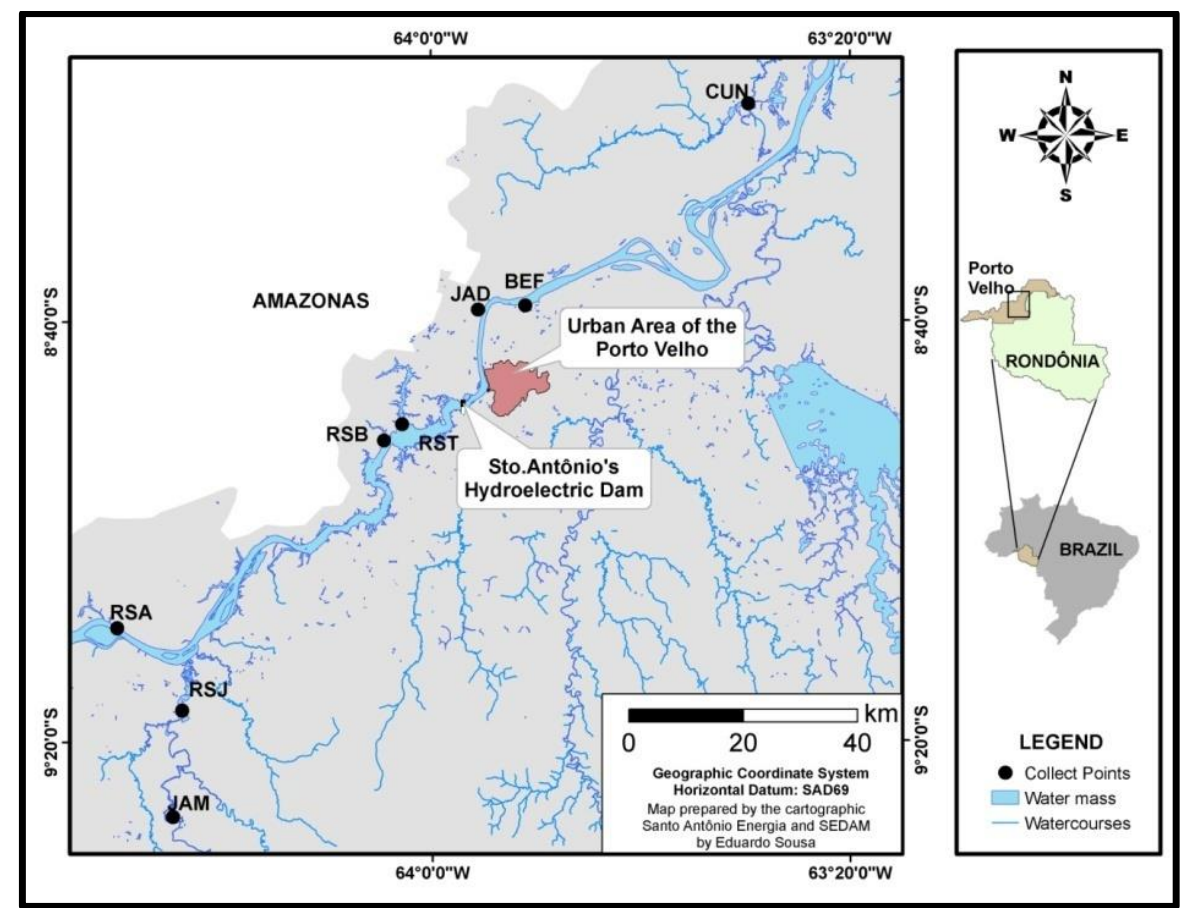

Figure 1. Overview of sampling area and sampling sites. 


\subsection{Fish samples}

Specimen fish were captured from the Madeira River between July $26^{\text {th }}$ and August 5th, 2012, using resources provided by the Ichthyofauna Monitoring and Conservation Program. This period is characterized by a descending water level. However, the collection period was not considered an important factor in our study. The specimens were collected using gill nets (3 to $20 \mathrm{~cm}$ mesh) with standardized effort, exposed for a period of 24 hours, and verified every 4 hours. The species Schizodon fasciatus (herbivorous), Potamorhina latior (detritivorous), Triportheus angulatus (omnivorous), Plagioscion squamosissimus (carnivorous) and Raphiodon vulpinus (piscivorous) were chosen because they were abundant in number, have different feeding habits and are often consumed by the riverine population, except for Raphiodon vulpinus. The fish sampling was authorized by the System Authorization and Information on Biodiversity (SISBIO) $n^{\circ} 4155$. Voucher specimens were deposited in the ichthyologic collection of the Universidade Federal de Rondônia (UFRO-I) (Schizodon fasciatus: UFRO-I 18586, Potamorhina latior: UFRO-I 17204, Triportheus angulatus: UFRO-I 15031, Plagioscion squamosissimus: UFRO-I 15063 and Raphiodon vulpinus: UFRO-I 15156).

\subsection{Acid chemical digestion and analysis}

\subsubsection{Mercury (Hg)}

Mercury $(\mathrm{Hg})$ concentration was determined according to Bastos et al. (1998). Around $1.0 \mathrm{~mL}$ of hydrogen peroxide $\left(\mathrm{H}_{2} \mathrm{O}_{2}\right.$, Tédia, Brazil) and $4.0 \mathrm{~mL}$ of sulfonitric solution $1: 1$ ( $\mathrm{HNO}_{3}: \mathrm{H}_{2} \mathrm{SO}_{4}$, Tédia, Brazil) were added to approximately $0.4 \mathrm{~g}$ of fish muscle (wet weight) for non-carnivorous fish and $0.2 \mathrm{~g}$ (wet weight) for carnivorous. The samples were then heated on the block digester (Tecnal, Mod.007A, Piracicaba, São Paulo, Brazil) at $70{ }^{\circ} \mathrm{C}$ for 30 minutes with a subsequent addition of $5.0 \mathrm{~mL}$ of potassium permanganate $\left(\mathrm{KMnO}_{4}\right.$, Merck) $5 \%(\mathrm{w} / \mathrm{v})$ and then heated on the block digester at $70{ }^{\circ} \mathrm{C}$ for 20 minutes. After $12 \mathrm{~h}$, around $1.0 \mathrm{~mL}$ hydroxylamine hydrochloride $\left(\mathrm{NH}_{2} \mathrm{OH}: \mathrm{HCl}\right.$, Tédia, Brazil) $12 \%(\mathrm{w} / \mathrm{v})$ was added to the samples. Samples volumes were adjusted to $11.0 \mathrm{~mL}$ with ultra pure water (Milli-Q Plus, Millipore, Billerica, USA) in polypropylene tubes. The sample analysis of total mercury was done by an atomic absorption spectrometer by cold vapor (FIMS-400, Perkin-Elmer, Waltham, USA).

\subsubsection{Zinc (Zn), Lead (Pb), Chromium (Cr), Nickel (Ni) and Copper (Cu)}

The Akan et al. (2012) method was adapted for acid chemical digestion and determination as follows: After weighting around $10 \mathrm{~g}$ (ww) of fish muscle tissue, samples were dried $\left(105^{\circ} \mathrm{C} / 48 \mathrm{~h}\right)$ and burnt $\left(400{ }^{\circ} \mathrm{C} / 48 \mathrm{~h}\right)$. Then, $3.0 \mathrm{~mL}$ of nitric acid $\left(\mathrm{HNO}_{3}\right.$, Tédia, Brazil) $68 \%(\mathrm{w} / \mathrm{w})$ was added to ashes and samples were placed on a hot digestion plate (Tecnal, Mod.007A, Piracicaba, São Paulo, Brazil) to evaporate $\left(120^{\circ} \mathrm{C}\right)$. Afterwards, $2.0 \mathrm{~mL}$ of hydrochloric acid ( $\mathrm{HCl}$, Tédia, Brazil) $37 \%$ (w/w) was added to the samples and which were then subjected to a hot digestion plate. After complete hydrochloric acid volatilization the samples were suspended by adding $15 \mathrm{~mL}$ of $\mathrm{HCl} 0.1 \mathrm{~N}$, and filtered (cellulose filters, $0.45 \mu \mathrm{m}$, Whatman). Samples analysis was done by a flame atomic absorption spectrometer (AAnalyst 400, Perkin-Elmer, Waltham, USA).

\subsection{Analytical control and statistical analysis}

Certified samples DOLT-2 (National Research Council - Canada) was used for Zn, Cu and $\mathrm{Cr}$ analytical control. SS2 (SCP-Science) was used to certify values for $\mathrm{Pb}$ and $\mathrm{Ni}$, and AFPX-5130 (Fish Internal Reference Laboratory) for total-Hg.

Descriptive analysis and statistical tests were performed using XLSTAT version 2014 (Addinsoft - France) software. The Shapiro-Wilk Test and Kruskal-Wallis Test, supported by 
Dunn's multiple comparison procedure, were used to compare the values between the specimens collected upstream and downstream (5\% significance).

\section{RESULTS}

\subsection{Trace metal concentrations}

Table 1 shows the average concentrations of six trace metals in five species of Amazonian fish sampled upstream and downstream of Santo Antonio's Hydroelectric Dam (Porto Velho City) in the Madeira River.

Table 1. Average trace metal concentrations (mg. $\mathrm{kg}^{-1}$ - wet weight) in five fish species of the Madeira River Basin sampled upstream $(U)$ and downstream $(D)$ of Porto Velho City. $\mathrm{n}=$ number of specimens.

\begin{tabular}{|c|c|c|c|c|c|c|c|c|c|c|c|c|c|c|}
\hline \multirow[b]{2}{*}{ Species } & \multicolumn{2}{|c|}{$\underline{\mathrm{Hg}}$} & \multicolumn{2}{|c|}{$\underline{\mathrm{Cu}}$} & \multicolumn{2}{|c|}{$\underline{\mathrm{Zn}}$} & \multicolumn{2}{|c|}{$\underline{\mathrm{Pb}}$} & \multicolumn{2}{|c|}{$\underline{\mathrm{Cr}}$} & \multicolumn{2}{|c|}{$\underline{\mathrm{Ni}}$} & \multicolumn{2}{|c|}{$\underline{\mathrm{n}}$} \\
\hline & $\underline{U}$ & $\underline{D}$ & $\underline{U}$ & $\underline{D}$ & $\underline{U}$ & $\underline{D}$ & $\underline{U}$ & $\underline{D}$ & $\underline{U}$ & $\underline{D}$ & $\underline{U}$ & $\underline{D}$ & $\underline{U}$ & $\underline{D}$ \\
\hline P. latior & 0.10 & 0.14 & 0.25 & 0.39 & 4.08 & 7.21 & 0.50 & 0.58 & 0.16 & 0.62 & 0.19 & 0.14 & 26 & 11 \\
\hline S. fasciatus & 0.07 & 0.11 & 0.21 & 0.30 & 4.59 & 9.01 & 0.52 & 0.68 & 0.24 & 0.57 & 0.14 & 0.15 & 11 & 08 \\
\hline T. angulatus & 0.31 & 0.19 & 0.21 & 0.38 & 7.32 & 8.09 & 0.50 & 0.68 & 0.37 & 0.41 & 0.18 & 0.09 & 13 & 21 \\
\hline P. squaтоsissimus & 0.33 & - & 0.10 & - & 3.85 & - & 0.36 & - & 0.09 & - & 0.14 & - & 41 & - \\
\hline R. vulpinus & 0.56 & 0.72 & 0.26 & 0.39 & 5.29 & 7.15 & 0.45 & 0.79 & 0.16 & 0.53 & 0.16 & 0.16 & 22 & 04 \\
\hline ANVISA $^{1}$ & \multicolumn{2}{|c|}{$\begin{array}{l}\mathbf{0 . 5 0 ^ { \mathrm { a } }} \\
\mathbf{1 . 0 0}^{\mathrm{b}}\end{array}$} & \multicolumn{2}{|c|}{30.00} & \multicolumn{2}{|c|}{$\mathbf{5 0 . 0 0}$} & \multicolumn{2}{|c|}{2.00} & \multicolumn{2}{|c|}{0.10} & \multicolumn{2}{|c|}{5.00} & & \\
\hline Recovery $(\%)^{2}$ & \multicolumn{2}{|c|}{103} & \multicolumn{2}{|c|}{94} & \multicolumn{2}{|c|}{106} & \multicolumn{2}{|c|}{110} & \multicolumn{2}{|c|}{107} & \multicolumn{2}{|c|}{98} & & \\
\hline
\end{tabular}

${ }^{1}$ Maximum limits for inorganic contaminants in non-carnivorous ${ }^{\mathbf{a}}$ and carnivorous ${ }^{\mathbf{b}}$ fish.

${ }^{2}$ Analytical recoveries.

Descriptive data shows that only chromium exceeded the permitted value for consumption established by ANVISA, being 6.2-times higher than the allowed value in $P$. latior sampled downstream. Only P. squamosissimus shows values below the allowed values for all trace metals in this study. Apparently, specimens sampled downstream show higher values of trace metals, except nickel, than specimens sampled upstream. Statistical tests were performed in $P$. latior, $T$. angulatus and $S$. fasciatus, because these species were very representative (n) both upstream and downstream (Table 1). The Shapiro-Wilk Test indicated that the groups compared (upstream and downstream of Porto Velho City) among species $P$. latior, S. fasciatus and T. angulatus presented non-normal distribution of the data $(\mathrm{p}<0.05)$. Therefore, the nonparametric Kruskal-Wallis Test supported by Dunn's multiple comparison procedure was used to compare groups of each species. The Kruskal-Wallis Test indicated a significant difference $(\mathrm{p}<0.0001)$ between the groups only for $\mathrm{Cr}$ in $P$. latior (Figure 2). The other trace metals were not significantly different $(\mathrm{p}>0.05)$ among the groups analyzed.

\subsection{Estimated daily intake in adults}

As chromium was the only contaminant with values above the established thresholds for food, special attention was given to this element. Therefore, we estimated daily adult intake for this trace metal. The daily adult intake estimation was arrived at through use of the equation presented in D'Amato et al. (2007) as adapted below: 


$$
\mathrm{EDI}=\frac{(\mathrm{CC} \cdot \mathrm{DI})}{\mathrm{BW}} \cdot 1000
$$

where:

EDI: estimated daily intake $\left(\mu \mathrm{g} \cdot \mathrm{day}^{-1}\right)$;

$\mathrm{CC}$ : chromium concentration in fish ( $\left.\mathrm{mg} \cdot \mathrm{kg}^{-1}\right)$;

DI: fish daily intake $\left(\mathrm{kg}^{-d a y}{ }^{-1}\right)$; and BW: body weight $(\mathrm{kg})$.

$\mathrm{Hg}$

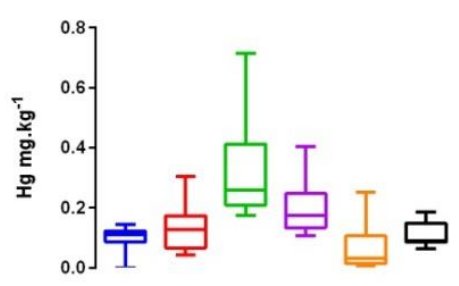

Zn

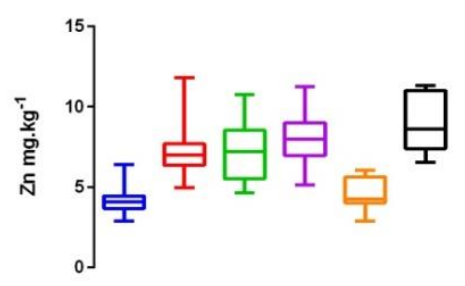

$\mathrm{Cr}$

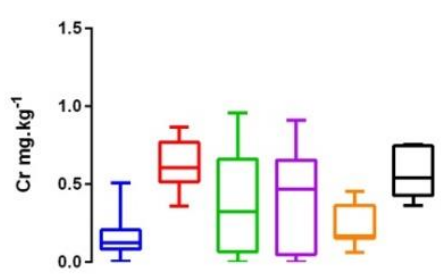

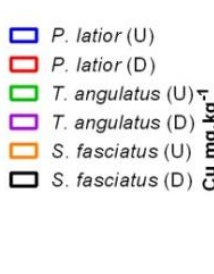

$\square$ P. latior $(\mathrm{U})$
$\square$ P. latior $(\mathrm{D})$
$\square$ T. angulatus $(\mathrm{U})$
$\square$ T. angulatus $(\mathrm{D})$
$\square$ S. fasciatus $(\mathrm{U})$
$\square$ S. fasciatus $(\mathrm{D}) \mathrm{U}$

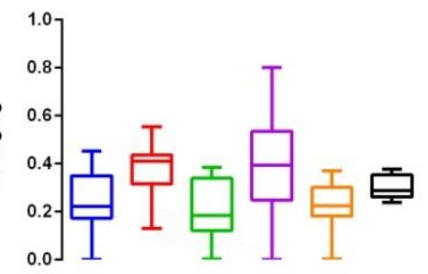

$\square$ P. latior (U)

$\square$ P. latior (D)

$\square T$. angulatus $(\mathrm{U}$

$\square T$. angulatus $(D$

$\square$ S. fasciatus (U)

$\square$ s. fasciatus (D)

Figure 2. Median, minimum and maximum concentrations in specimens of species $P$. latior, T. angulatus and S. fasciatus sampled upstream (U) and downstream (D) of Porto Velho City.

Table 2 shows the values obtained regarding estimated daily intake from consumption of each species analyzed. The values assume a daily fish intake conforming to the average Brazilian fish consumption (Brasil, 2013), the average riverine fish consumption (Oliveira et al., 2010) and an adult body weight of $70 \mathrm{~kg}$. The recommended daily intake is based on resolution No. 269/2005, established by ANVISA. 
Table 2. Estimated daily intake of chromium $\left(\mu \mathrm{g} . \mathrm{day}^{-1}\right)$ from consumption of five Amazonian fish species based on Brazilian fish consumption (BFC), Amazonian riverine fish consumption (RFC) and recommended daily intake (RDI) established by ANVISA (2005).

\begin{tabular}{|c|c|c|c|c|c|}
\hline & \multicolumn{2}{|c|}{$\mathrm{BFC}$} & \multicolumn{2}{|c|}{ RFC } & \multirow{2}{*}{ RDI } \\
\hline & Upstream & Downstream & Upstream & Downstream & \\
\hline P. latior & 0.07 & 0.27 & 0.93 & 3.60 & \\
\hline S. fasciatus & 0.10 & 0.25 & 1.39 & 3.31 & \\
\hline T. angulatus & 0.16 & 0.18 & 2.15 & 2.38 & 35 \\
\hline P. squamosissimus & 0.04 & - & 0.52 & - & \\
\hline R. vulpinus & 0.07 & 0.23 & 0.93 & 3.07 & \\
\hline
\end{tabular}

\section{DISCUSSION}

The Brazilian Health Surveillance Agency (ANVISA) establishes the maximum of inorganic contaminants in foods (Table 1) according to Decree No. 55871/65 (ANVISA, 1965) and Decree No. 685/98 (ANVISA, 1998). The results indicated that national regulatory pollution limits were exceeded in the specimens sampled only for Chromium $(\mathrm{p}<0.0001)$, especially in $P$. latior collected downstream. This may reflect anthropogenic influence coupled with the ecological behavior of the species. Chromium is water insoluble (mainly in $\mathrm{Cr}$ III form), being removed from the water column via adsorption-coagulation processes with suspended matter and deposited in bottom sediment (Pawlikowski et al., 2006; Szalinska et al., 2010). P. latior has a detritivorous feeding habit, foraging on river bottoms (Vari and Röpke, 2013), which increases its exposure to higher bio-concentrations of chromium than species with different foraging habits.

Estimated chromium daily intake was higher in fish from downstream than upstream. When compared with average Brazilian fish consumption and Amazonian riverine average fish consumption, the values are as much as 13 times higher in an Amazonian riverine adult, due to his large daily intake of fish. Although the estimated daily intake of chromium is greater in riverine populations, the values obtained are below the recommended daily intake by ANVISA (2005). However, an increase of sewage or untreated industrial effluents releases into rivers can increase the daily chromium intake of riverine populations, thereby affecting their health. $\mathrm{Cr}$ in a trivalent state (Cr III) is essential for biochemical and physiological processes of organisms influencing, for example, the processes of the degradation of sugar by the action of insulin (ATSDR, 2012). However, in hexavalent state (Cr VI) chromium is potentially carcinogenic; it can easily penetrate cells and bind to DNA molecules (Langerwerf et al, 1985; O'Flaherty, 1993).

Industrial tanneries are other activities that may influence $\mathrm{Cr}$ concentration in the Madeira River fish. In the leather tanning process, a chemical compound containing $\mathrm{Cr}$ is used to stiffen the hide and ensure the product's preservation. During this process, a sludge rich in chromium is produced that in most cases is not adequately treated and is then dumped directly into the aquatic bodies (Godecke et al., 2012). Currently, Porto Velho City has two licensed tanneries in operation, both installed near rivers and creeks that flow into the Madeira River, and there are reports of small-scale tanneries working illegally near the river as well.

All of the other chemical elements studied presented concentrations within the permitted values for consumption in the species analyzed. Nevertheless, the ANVISA regulations emphasize the importance of periodic reviews of these elements, especially $\mathrm{Pb}$ and $\mathrm{Hg}$, because while they are not essential, they can still serve as a check on heavy metal 
contamination in the most consumed fish species originating from the Madeira River Basin. The results obtained for $\mathrm{Zn}, \mathrm{Cu}, \mathrm{Ni}, \mathrm{Pb}$ and $\mathrm{Cr}$ in fish muscles tissues are unprecedented in the region where the study was conducted; only $\mathrm{Hg}$ biogeochemistry was extensively studied. Bastos et al. (2008) verified mercury concentrations in several species with varied feeding habits collected in the Madeira River Basin, among them $S$. fasciatus, $P$. latior, $P$. squamosissimus and $R$. vulpinus. The Triportheus genus was represented by $T$. elongatus in their study. The concentrations found were similar to those found in this study $(0.12,0.11$, $0.18,0.44$ and $0.93 \mathrm{mg} . \mathrm{kg}^{-1}$ for $S$. fasciatus, $P$. latior, T. elongatus, $P$. squamosissimus and $R$. vulpinus, respectively), indicating that concentrations hardly changed during the studied periods.

While $\mathrm{Zn}, \mathrm{Cu}, \mathrm{Ni}, \mathrm{Pb}$ and $\mathrm{Hg}$ do not exceed national regulatory thresholds, it is known that they may have acute or chronic effects on organisms in aquatic environments even in small doses. Serious sub-lethal direct effects can occur, affecting animal behavior at concentrations much less than those at which they have lethal effects. For example, metal pollutants may influence immune responses of organisms, affecting pathogen-host interactions and modifying immune system function, stimulating or reducing it. Indirect effects may be found throughout their interactions with the structure of food webs in aquatic communities, for example, alterations in predator/prey interaction (Boyd, 2010).

Madeira River has a great stock of fish that drives the regional economy and is the main economic activity of the riverine population. Lately, many events have occurred in the river, such as the construction of hydroelectric dams and unusual flooding, which may alter the dynamics of trace metals, which may in turn affect the stock of the main economic fish species. Therefore, our results suggest future research is necessary regarding about trace metals in the fish of the Madeira River and the surrounding area, mainly related to fishes' response to trace metals.

\section{CONCLUSIONS}

Except for chromium, the results demonstrated that heavy metal concentrations are below the maximum limits established for human consumption by ANVISA. In the comparison of the metal concentrations in specimens sampled upstream and downstream of the Porto Velho City, Potamorhina latior showed the highest concentrations in the downstream area for Cr. This indicates that Porto Velho City may influence the increase of chromium concentrations in fish tissue, due to inadequate treatment of sewage dumped directly into the Madeira River. Estimated daily intake of chromium showed higher values in fish sampled downstream than upstream and are 13 times higher in an adult riverine than in an adult from other region of Brazil.

\section{ACKNOWLEDGEMENT}

We would like to thank Laboratório de Ictiologia e Pesca of Universidade Federal de Rondônia for fish collection and identification. This study was supported by grants from SAE and CNPq (Grants no.552331/2011-2 and 400576/2013-9).

\section{REFERENCES}

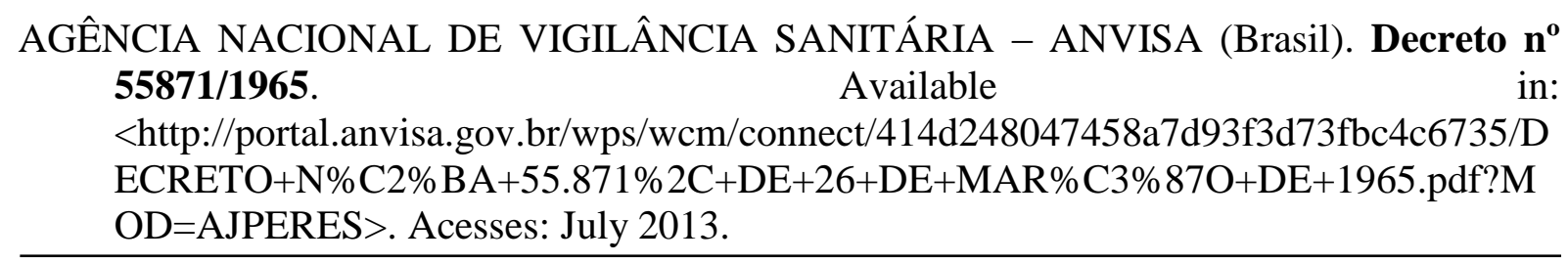

Rev. Ambient. Água vol. 10 n. 3 Taubaté - Jul. / Sep. 2015 
AGÊNCIA NACIONAL DE VIGILÂNCIA SANITÁRIA - ANVISA (Brasil). Portaria no 685/1998. Available in: <http://portal.anvisa.gov.br/wps/wcm/connect/8c494f8047 45801a8c00dc3fbc4c6735/PORTARIA+N+\%C2\%BA+685\%2C+DE+27+DE+AGOST O+DE+1998.pdf?MOD=AJPERES>. Acesses: April 2013.

AGÊNCIA NACIONAL DE VIGILÂNCIA SANITÁRIA - ANVISA (Brasil). Resolução 269/05 Regulamento técnico sobre a ingestão diária recomendada (IDR) de proteínas, vitaminas e minerais. Available in: <http://portal.anvisa.gov.br/wps/ wcm/connect/1884970047457811857dd53fbc4c6735/RDC_269_2005.pdf?MOD=AJPE RES>. Accesses: October 2014.

AGENCY FOR TOXIC SUBSTANCES AND DISEASE REGISTRY - ATSDR. Toxicological profile for Chromium. 2012. Available in: <http://www.atsdr.cdc.gov/ToxProfiles/tp7.pdf>. Accesses: February 2014.

AKAN, J. C.; SALWA, M.; YIKALA, B. S.;CHELLUBE, Z. M. Study on the Distribution of Heavy Metals in Different Tissues of Fishes from River Benue in Vinikilang, Adamawa State, Nigeria. British Journal of Applied Science \& Technology, v. 2, n. 4, p. 311333, 2012.

BASTOS, W. R.; MALM, O.; PFEIFFER, W. C.; CLEARY, D. Establishment and analytical quality control of laboratories for $\mathrm{Hg}$ determitation in biological and geological samples in the Amazon, Brasil. Ciência e Cultura, v. 50, n. 4, p. 255-260, 1998.

BASTOS, W. R.; GOMES, J. P. O.; OLIVEIRA, R. C.; ALMEIDA, R.; NASCIMENTO, E. L.; BERNARDI, J. V. E. et al. Mercury in the environment and riverside population in the Madeira River Basin, Amazon, Brazil. Science of Total Environment, v. 368, n. 1, p. 344-351, 2006. http://dx.doi.org/10.1016/j.scitotenv.2005.09.048

BASTOS, W. R.; ALMEIDA, R.; DÓREA, J. G.; BARBOSA, A. C. Annual flooding and fish-mercury bioaccumulation in the environmentally impacted Rio Madeira (Amazon). Ecotoxicology, v. 16, n. 3, p. 341-346, 2007. http://dx.doi.org/10.1007/s10646-0070138-0

BASTOS, W. R.; REBELO, M. F.; FONSECA, M. F.; ALMEIDA, R.; MALM, O. A description of Mercury in fishes from the Madeira river basin, Amazon, Brazil. Acta Amazonica, v. 38, n. 3, p. 431-438, 2008. http://dx.doi.org/10.1590/S004459672008000300006

BOYD, R. S. Heavy metal pollutants and chemical ecology: exploring new frontiers. Journal of Chemical Ecology, v. 36, p. 46-58, 2010. http://dx.doi.org/10.1007/s10886-0099730-5

BRASIL. Ministério da Pesca e Aquicultura - MPA. Consumo de pescado no Brasil aumenta $23,7 \%$ em dois anos. Portal Brasil, 17 out. 2013. Available in: $<$ http://www.brasil.gov.br/economia-e-emprego/2013/10/consumo-de-pescado-nobrasil-aumenta-23-7-em-dois-anos>. Accesses: October 2014.

DORIA, C. R. C.; RUFFINO, M. L.; HIJAZI, N. C.; CRUZ, R. L. A pesca comercial na bacia do rio Madeira no estado de Rondônia, Amazônia brasileira. Acta Amazonica, v. 42, n. 1, p. 29-40, 2012. http://dx.doi.org/10.1590/S0044-59672012000100004

D'AMATO, C.; TORRES, J. P. M.; MALM, O. Determinação de $\sum$ DDT encontradas em peixes comestíveis de diferentes áreas da Amazônia brasileira. Oecologia Brasiliensis, v. 11, n. 2, p. 202-212, 2007. 
GODECKE, M. V.; RODRIGUES, M. A. S.; NAIME, R. H. Resíduos de curtumes: estudos das tendências de pesquisa. REGET/UFSM, v. 7, n. 7, p. 1357-1378, 2012. http://dx.doi.org/10.5902/223611705779

LANGERWERF, J. S. A.; BAKKEREN, H. A.; JONGEN, W. M. T. A comparison of the mutagenicity of soluble trivalent chromium compounds with that of potassium chromate. Ecotoxicology and Environmental Safety, v. 9, n. 1, p. 92-100, 1985. http://dx.doi.org/10.1016/0147-6513(85)90039-9

MAURICE-BOURGOIN, L.; QUIROGA, I.; CHICHEROS, J.; COURAU, P. Mercury distribution in waters and fishes of the upper Madeira River and mercury exposure in riparian Amazonian population. Science of Total Environment, v. 260, p. 73-86, 2000. http://dx.doi.org/10.1016/S0048-9697(00)00542-8

MISHRA, A. K.; MOHANTY, B. Chronic exposure to sublethal hexavalent chromium affects organ histopathology and serum cortisol profile of a teleost, Channa punctatus (Bloch).

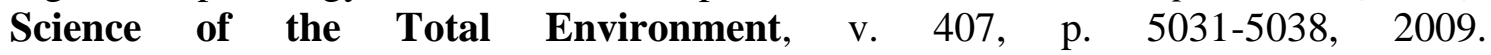
http://dx.doi.org/10.1016/j.scitotenv.2009.05.042

NAGPURE, N. S.; SRIVASTAVA, R.; KUMAR, R.; KUSHWAHA, B.; SRIVASTAVA, S. K.; KUMAR, P. et al. Assessment of genotoxic and mutagenic potential of hexavalent chromium in the freshwater fish Labeo rohita (Hamilton, 1822). Drug and Chemical Toxicology, v. 38, n. 1, p. 9-15, 2015. http://dx.doi.org/10.3109/01480545.2014.900066

NATIONAL ACADEMY OF SCIENCES. Principles for evaluating Chemicals in the Environment. Washington, D.C., 1975

O'FLAHERTY, E. J. Chromium as an essential and toxic metal. Scandinavian Journal of Work, Environment \& Health, v. 19, p. 124-125, 1993. Suppl. 1.

OLIVEIRA, R. C.; DÓREA, J. G.; BERNARDI, J. V. E.; BASTOS, W. R.; ALMEIDA, R.; MANZATTO, A. G. Fish consumption by traditional subsistence villagers of the Rio Madeira (Amazon): Impact on hair mercury. Annals of Human Biology, v. 37, n.5, p. 629-642, 2010. http://dx.doi.org/10.3109/03014460903525177

PAWLIKOWSKI, M.; SZALINSKA, E.; WARDAS, M.; DOMINIK, J. Chromium originating from tanneries in river sediments: a preliminary investigation from the Upper Dunajec river (Poland). Polish Journal of Environmental Study, v. 15, n. 6, p. 885-894, 2006.

PELICICE, F. M.; AGOSTINHO, A. A. Fish passage facilities as ecological traps in large Neotropical rivers. Conservation Biology, 22, n. 1, p.180-188, 2008. http://dx.doi.org/10.1111/j.1523-1739.2007.00849.x

PFEIFFER, W. C.; LACERDA, L. D. Mercury inputs into the Amazon region, Brazil. Environmental Science and Technology Letters, v. 9, n. 4, p. 325-330, 1988. http://dx.doi.org/10.1080/09593338809384573

POMPEU, P. S.; AGOSTINHO, A. A.; PELICICE, F. M. Existing and future challenges: the concept of successful fish passage in South America. River Research and Applications, v. 28, n. 4, p. 504-512, 2012. http://dx.doi.org/10.1002/rra.1557

SANTOS, J. P.; SOUZA, D. O.; MIRANDA, M. R.; BASTOS, W. R. Estudos de elementostraço na cidade de Porto Velho/Rondônia, Amazônia Ocidental. Journal of the 
$\begin{array}{lllllllll}\text { Brazilian Society of Ecotoxicology, } & \text { v. } & 7, & \text { n. } & 2, & \text { p. } & 1-9, & 2012 .\end{array}$ http://dx.doi.org/10.5132/jbse.2012.02.001

SUBOTIC, S.; SPASIC, S.; VISNJIC-JEFTIC, Z.; HEGEDIS, A.; KRPO-CETKOVIC, J.; MICKOVIC, B. et al. Heavy metal and trace element bioaccumulation in target tissues of four edible fish species from the Danube river (Serbia). Ecotoxicology and Environmental Safety. v. 98, p. 196-202, 2013. http://dx.doi.org/10.1016/j.ecoenv.2013.08.020

SZALINSKA, E.; DOMINIK, J.; VIGNATI, D. A. L.; BOBROWSKI, A.; BAS, B. Seasonal transport pattern of chromium (III and VI) in a stream receiving wastewater from tanneries. Applied Geochemistry, v. 25, p. 116-122, 2010. http://dx.doi.org/10.1016/j.apgeochem.2009.11.002

VARI, R. P.; RÖPKE, C. P. Curimatideos. In: QUEIROZ, L. J.; TORRENTE-VILARA, G.; OHARA, W. M.; PIRES, T. H. S.; ZUANON, J. A. S.; DORIA, C. R. C. (Eds.). Peixes do rio Madeira. São Paulo: Dialeto Latin American Documentary, 2013. p.112-139.

WELCH, E. B.; JACOBY, J. M. Pollutant effects in freshwater: applied limnology. 3rd Edition. London: Taylor \& Francis Group, 2004. 